\title{
Prevalence of and factors associated with significant bacteriuria among pregnant women attending the antenatal clinic of Adeoyo Maternity Hospital, Yemetu, Ibadan, Nigeria
}

\author{
${ }^{{ }^{*}}$ Jamiu, M. O., ${ }^{2}$ Okesola, A. O., ${ }^{3}$ Ogunleye, V. O., and ${ }^{1}$ Fasulu, P. E. \\ ${ }^{1}$ Department of Biomedical Laboratory Science, College of Medicine, University of Ibadan, Nigeria \\ ${ }^{2}$ Department of Medical Microbiology and Parasitology, College of Medicine, University of Ibadan, Nigeria \\ ${ }^{3}$ Oyo State Emergency Operations Centre, Ibadan, Nigeria \\ *Correspondence to: jamiumonsur@gmail.com;+234-703-285-9663
}

\begin{abstract}
:
Background: Significant bacteriuria is commonly reported in pregnancy which greatly predisposes pregnant women to urinary tract infection (UTI), one of the commonest health challenges in pregnancy worldwide especially in developing countries such as Nigeria. The objectives of this study are to determine the prevalence of and factors associated with significant bacteriuria among pregnant women attending the antenatal clinic (ANC) of Adeoyo Maternity Hospital, Yemetu, Ibadan, Nigeria, as well as determine the bacterial aetiology and antimicrobial susceptibility patterns of the isolates.

Methodology: This is a laboratory-based cross-sectional study of 206 pregnant women between the ages of 15 and 47 years attending the ANC of the hospital, selected by simple random sampling method. Demographic and clinical data were obtained from the subjects using a structured questionnaire. Clean-catch specimen of mid-stream voided urine was collected from each subject participant. Urine samples were processed for culture and isolation of significant bacterial pathogens using standard bacteriological methods, and isolates identified to species level by the combination of colony morphology, Gram reaction, conventional biochemical tests and Analytical Profile Index (API) $20 \mathrm{E}$ test kits. Antibiotic susceptibility testing of the isolates to selected antibiotics was performed using the disk diffusion method.

Results: The prevalence of significant bacteriuria in the study population was $8.7 \%(18 / 206)$, with $27.8 \%(5 / 18)$ symptomatic and $72.2 \%(13 / 18)$ asymptomatic. All isolated bacteria were Gram-negative with the most frequent being Escherichia coli 9 (50.0\%), followed by Klebsiella pneumoniae 6 (33.3\%), Pseudomonas aeruginosa 1 $(5.6 \%)$, Acinetobacter haemolyticus 1 (5.6\%) and Enterobacter aerogenes 1 (5.6\%). The isolates were most sensitive to gentamicin $(100 \%)$ and nitrofurantoin $(94.4 \%)$, while they demonstrated highest resistance to amoxicillin-clavulanic acid (33.3\%). Significant bacteriuria was associated with pyuria $(p=0.01)$ and past history of UTI $(p=0.004)$.

Conclusions: The high prevalence of asymptomatic significant bacteriuria in this study necessitates the need for screening and treatment of pregnant women for this entity to prevent the subsequent development of UTI that may have grave consequences on pregnancy outcome.
\end{abstract}

Keywords: urinary tract infection; significant bacteriuria; pregnant women; factors

Received Jul 1, 2021; Revised Aug 3, 2021; Accepted Aug 4, 2021

Copyright 2021 AJCEM Open Access. This article is licensed and distributed under the terms of the Creative Commons Attrition 4.0 International License $<$ a rel="license" href="http://creativecommons.org/licenses/by/4.0/", which permits unrestricted use, distribution and reproduction in any medium, provided credit is given to the original author(s) and the source. Editor-in-Chief: Prof. S. S. Taiwo

\section{Prévalence et facteurs associés à une bactériurie significative chez les femmes enceintes fréquentant la clinique prénatale de la maternité Adeoyo, Yemetu, Ibadan, Nigéria}

\author{
${ }^{* 1}$ Jamiu, M. O., ${ }^{2}$ Okesola, A. O., ${ }^{3}$ Ogunleye, V. O., et ${ }^{1}$ Fasulu, P. E.
}

${ }^{1}$ Département des sciences de laboratoire biomédical, Faculté de médecine, Université d'Ibadan, Nigéria

${ }^{2}$ Département de microbiologie médicale et de parasitologie, Faculté de médecine, Université d'Ibadan, Nigéria

${ }^{3}$ Centre des opérations d'urgence de l'État de 30yo, Ibadan, Nigéria

*Correspondance à:jamiumonsur@gmail.com; +234-703-285-9663 


\section{Abstrait:}

Contexte: Une bactériurie importante est couramment signalée pendant la grossesse, ce qui prédispose grandement les femmes enceintes aux infections des voies urinaires (IVU), l'un des problèmes de santé les plus courants pendant la grossesse dans le monde, en particulier dans les pays en développement comme le Nigéria. Les objectifs de cette étude sont de déterminer la prévalence et les facteurs associés à une bactériurie significative chez les femmes enceintes fréquentant la clinique prénatale (CPN) de I'hôpital de maternité Adeoyo, Yemetu, Ibadan, Nigéria, ainsi que de déterminer l'étiologie bactérienne et les modèles de sensibilité aux antimicrobiens de les isolats.

Méthodologie: Il s'agit d'une étude transversale en laboratoire portant sur 206 femmes enceintes âgées de 15 à 47 ans fréquentant les CPN de I'hôpital, sélectionnées par une méthode d'échantillonnage aléatoire simple. Les données démographiques et cliniques ont été obtenues auprès des sujets à l'aide d'un questionnaire structuré. Un échantillon propre d'urine évacuée à mi-chemin a été recueilli auprès de chaque participant sujet. Les échantillons d'urine ont été traités pour la culture et l'isolement d'agents pathogènes bactériens importants à l'aide de méthodes bactériologiques standard, et les isolats ont été identifiés au niveau de l'espèce par la combinaison de la morphologie de la colonie, de la réaction de Gram, des tests biochimiques conventionnels et des kits de test de l'indice de profil analytique (API) 20E. Les tests de sensibilité aux antibiotiques des isolats aux antibiotiques sélectionnés ont été effectués à l'aide de la méthode de diffusion sur disque.

Résultats: La prévalence de la bactériurie significative dans la population étudiée était de $8,7 \%(18 / 206)$, avec $27,8 \%(5 / 18)$ symptomatique et $72,2 \%(13 / 18)$ asymptomatique. Toutes les bactéries isolées étaient Gramnégatives, la plus fréquente étant Escherichia coli 9 (50,0\%), suivie de Klebsiella pneumoniae 6 (33,3\%), Pseudomonas aeruginosa 1 (5,6\%), Acinetobacter haemolyticus 1 (5,6\%) et Enterobacter aerogenes 1 (5,6\%). Les isolats étaient les plus sensibles à la gentamicine $(100 \%)$ et à la nitrofurantoïne $(94,4 \%)$, alors qu'ils présentaient la résistance la plus élevée à l'amoxicilline-acide clavulanique $(33,3 \%)$. Une bactériurie significative était associée à une pyurie $(p=0,01)$ et à des antécédents d'infection urinaire $(p=0,004)$.

Conclusions: La prévalence élevée de bactériurie significative asymptomatique dans cette étude nécessite le dépistage et le traitement des femmes enceintes pour cette entité afin de prévenir le développement ultérieur d'infections urinaires pouvant avoir de graves conséquences sur l'issue de la grossesse.

Mots-clés: infection des voies urinaires; bactériurie importante; femmes enceintes; les facteurs

\section{Introduction:}

The urinary system includes the organs involved in the formation, collection, storage, and excretion of urine from the body, which includes two kidneys, two ureters, a bladder and urethra. Urine formed in the kidney is a sterile fluid that can serve as a good culture medium for proliferation of bacteria (1). The urethra however may contain few commensals and also the perineum has a wide variety of Gram-positive and Gram-negative organisms which can contaminate urine during voiding. In the females, urine may become contaminated with organisms from the vagina which is often indicated by the presence of epithelial cells (moderate to many) and a mixed bacterial flora.

Urinary tract infection (UTI) is the inflammation of the urinary tract caused by the presence and multiplication of microorganisms. It is perhaps the single most common bacterial infection of mankind (2). The normal urinary tract is resistant to colonization and subsequent infection by bacteria except for the urethral mucosa and the renal medulla, which appear to be relatively susceptible to colonization and subsequent infection because the urinary tract can efficiently and rapidly eliminate virulent and non-virulent microorganisms. UTI is known to cause short-term morbidity in terms of fever, dysuria, and lower abdominal pain but may result in permanent scarring of the kidneys. All age groups and gender are affected although UTI is commoner in females than males due to the shortness of the female urethra, pregnancy and easy contamination of the urinary tract with faecal flora. Urinary tract infection occurs in both hospitalized and nonhospitalized individuals, with serious impacts on the socio-economic life of the affected individual and the society, and also account for a large proportion of antibacterial drug consumption (3).

Urinary tract infection in pregnancy is among the most common health problems worldwide, especially in developing countries, which can lead to poor maternal and perinatal outcome. Untreated UTI can be associated with serious obstetric complications such as intrauterine growth retardation (IUGR), pre-eclampsia, caesarean section (CS) and preterm delivery. Both symptomatic and asymptomatic UTI are common in pregnancy, and asymptomatic bacteriuria can lead to pyelonephritis later in preg- nancy or during puerperium, with several adverse outcomes both on the mother and the fetus. Yasemi et al., (4) reported that children born by mothers with pyelonephritis are more prone to impairment of mental and motor development. Urinary tract infection in pregnancy commonly starts at week 6 and becomes 
most frequent during weeks 22-24 (5). Various physiological, anatomical, and personal factors contribute to this problem during pregnancy such as urethral dilation, increased bladder volume, and decreased bladder tone with urinary stasis. Moreover, a breach of personal hygiene increases the risk of infection. Furthermore, up to $70 \%$ of women during pregnancy have glucose in urine, which increases the chances of bacterial growth in the urine.

Investigation of UTI accounts for a significant part of the work load in clinical microbiology laboratories and enteric bacteria, in particular, Escherichia coli, remain the most frequent bacterial pathogen causing UTI, although there are changes in the types and distribution of pathogens involved in UTI (6). Bacteriuria (the presence of bacteria in urine) is said to be significant when there are at least 100,000 bacteria colonies of a single pathogen per milliliter in a freshly voided urine, collected by the mid-stream clean catch technique. The original criterion for diagnosis required $\geq 10^{5}$ CFU/ml on two consecutive clean catch samples (7). However, detection of $\geq 10^{5} \mathrm{CFU} / \mathrm{ml}$ in a single voided mid-stream urine sample is accepted as adequate and a more practical alternative (7). Contaminated cultures usually show fewer than $10^{3} \mathrm{CFU} / \mathrm{ml}$ of urine. Most voided urine specimens will contain fewer than $10^{4}$ contaminating organisms per $\mathrm{ml}$ provided the urine has been collected with care to minimize contamination and the specimen is examined soon after the collection before the commensal microbes significantly multiplied. Colony counts less than $10^{5} \mathrm{CFU} / \mathrm{ml}$ of urine can however be significant in patients with pyelonephritis, in whom the bacteria are multiplying mainly in the kidneys rather than in the urinary bladder, in patients with symptoms of lower UTI but with low colony counts which may indicate "urethral syndrome", patients with prostatitis and epididymitis, and patients with fungal UTI (8).

Urinary tract infection can be symptomatic or asymptomatic (9). Asymptomatic bacteriuria (ASB), which is sometimes used synonymously with asymptomatic UTI, is defined as the persistent and actively multiplying bacteria within the urinary tract without symptoms or signs (10). There are several factors associated with ASB including socioeconomic status with indigent women having a five-fold greater incidence of bacteriuria compared with non-indigent populations. Other factors reported to be significantly associated with ASB include diabetes, sickle cell disease and trait, multiparity, previous history of UTI, and anatomic or functional urinary tract abnormalities (11). Since
ASB and obvious UTI have a close association, screening and treatment of pregnant women with ASB may also help to reduce the adverse outcome such as preterm labour and low birth weight. Globally, the overall prevalence of significant bacteriuria in pregnancy is known to vary from $4 \%-7 \%$, although a range of $2-11 \%$ has been reported (12). However, the prevalence rate among pregnant Nigerian women has been variously reported to be between $1.3 \%-60 \%(6,13-23)$, but the prevalence in our hospital remains unknown. This study was therefore designed to determine the prevalence and factors associated with significant bacteriuria among pregnant women attending the antenatal clinic of Adeoyo Maternity Hospital, Yemetu, Ibadan, Nigeria, as well as to determine the bacteriology and antibiotic susceptibility of the isolates to commonly prescribed antibiotics in pregnancy in our environment.

\section{Materials and method:}

\section{Study area}

The study was conducted in Ibadan, the capital city of Oyo State, southwest Nigeria. Oyo State is divided into 33 Local Government Areas (LGAs) with an estimated population of 3.5 million. Ibadan, which occupies an area of $828 \mathrm{~km}^{2}$, lies on Longitude $3^{\circ} 5^{\prime}$ East of Greenwich meridian and Latitude $7^{\circ} 23^{\prime}$ North of the Equator. There are 11 LGAs in Ibadan metropolitan area consisting of five urban and six semi-urban LGAs. The population is large and heterogeneous with people of different religion, culture and ethnic groups, but predominantly of the Yoruba tribe.

\section{Study population, sample size and sampling}

The study population comprises pregnant women attending antenatal clinic of the hospital in January and February, 2020. The sample size was calculated using the Cochran formula; $N=Z /(D)^{2} p(1-p)$, where $N=$ sample size, $Z$ = standard normal value corresponding to $95 \%$ confidence interval set at $1.96, \mathrm{D}=$ degree of error tolerance at $5 \%, P=$ proportion used for estimation, obtained from previous studies in the study environment (14\% was chosen from prevalence range of $1.3 \%-60 \%$ reported in Nigeria). This gave the calculated sample size (N) of 185 , which was corrected for $10 \%$ non-response ( $r$ ) rate using the adjustment formula; $\mathrm{Nf}=\mathrm{N} /(1-r)$, to give the adjustted sample size of 206 .

Pregnant women between the ages of 15 to 47 years were consecutively recruited from the study population by the help of the nurses and midwives in the clinic using simple random sampling technique until the required 
sample size of 206 was obtained. Eligibility was based on willingness of the women to participate but those on any antibiotic therapy within two weeks preceding recruitment were excluded from the study.

\section{Ethical considerations}

The study proposal was approved by the University of Ibadan/University College Hospital Ethical committee and the Oyo State Ministry of Health. A written informed consent was obtained from each study participant.

\section{Data and sample collection}

Socio-demographic information such as age, occupation, and other clinical information such as parity and previous history of UTI were obtained using a structured questionnaire. About $10 \mathrm{ml}$ of clean catch specimen of voided early morning urine were collected from each subject into a sterile, screw-capped wide neck urine container, which had been correctly labeled and given to each subject. Each participant was instructed by the nurses and midwives on the method of urine collection to avoid contamination.

The specimens were transported to the Medical Microbiology and Parasitology laboratory of the University College Hospital (UCH), Ibadan in iced packs, and processed within one hour of collection. However, where immediate processing was not possible, the samples were refrigerated at $4^{\circ} \mathrm{C}$ to avoid bacteria multiplication.

\section{Microscopic examination of urine}

For urinary sediment examination, the urine samples were mixed and aliquots were centrifuged at $5000 \mathrm{rpm}$ for $5 \mathrm{~min}$. Deposits were examined using both $10 x$ and $40 x$ objectives of the light microscope. Microscopic findings of pyuria (leukocyte count $\geq 5$ /HPF) were considered as supportive evidence of UTI. A smear of the urine sample was made on a grease free clean slide, allowed to air dry, Gram stained, and examined microscopically using 100x (oil immersion) objective lens.

\section{Isolation \& identification of bacteria from urine}

The well-mixed urine sample was inoculated using a sterile calibrated wire loop $(0.001 \mathrm{ml})$ onto Cysteine Lactose Electrolyte Deficient (CLED) agar and 5\% sheep blood agar as described in Cheesbrough (24). The culture plates were incubated aerobically at $37^{\circ} \mathrm{C}$ for 24 hours. Colony counts yielding bacterial growth of $10^{5} \mathrm{CFU} / \mathrm{ml}$ ( $\geq 100$ colonies on culture plate) was regarded as significant bacteriuria.

Colonies of bacteria on culture plates showing significant growth were characterized and identified to species level by Gram stain, motility test, conventional biochemical test and commercial Analytical Profile Index (24). For identification using API, colonies from overnight cultures were reconstituted in normal saline to 4.0 McFarland standard from which aliquots were taken and inoculated onto API test strips. These strips were incubated at $36^{\circ} \mathrm{C}$ for 18 hours and then observed for colour reactions and the readings documented. The readings were translated into numbers and the numbers were interpreted into bacteria species using the API software.

\section{Antibiotic susceptibility testing}

Antibiotic susceptibility testing was performed on pure cultures of all significant isolated uropathogens using the disk diffusion method of Bauer et al., (25) against selected antibiotics (Oxoid, UK); amoxicillin/clavulanic acid $(20 / 10 \mu \mathrm{g})$, ceftriaxone $(30 \mu \mathrm{g})$, gentamicin $(10 \mu \mathrm{g})$, nitrofurantoin $(300 \mu \mathrm{g})$, ceftazidime (30 $\mu \mathrm{g})$, and cefuroxime $(30 \mu \mathrm{g})$.

Pure colonies of each isolate were suspended in $5 \mathrm{ml}$ normal saline to prepare the inoculum, which was standardized to $0.5 \mathrm{Mc}-$ Farland standard. The surface of Mueller-Hinton agar plates was inoculated with the suspension using sterile swabs, after which antibiotic disks were placed on the inoculated plates equidistant from each other, using sterile forceps and the plates incubated aerobically at $37^{\circ} \mathrm{C}$ for 24 hours. The diameters of zones of inhibition around each antibiotic disk were measured to the nearest millimeter using a caliper. Isolates were classified as sensitive, intermediate or resistant according to the CLSI (26) guidelines. Escherichia coli (ATCC 25922), Staphylococcus aureus (ATCC 25923) and Pseudomonas aeruginosa (ATCC 27853) were used as reference control strains for identification and susceptibility testing.

\section{Data analysis}

Data entry and analysis were done using SPSS version 25.0 software package. The frequency of bacteria isolation from urine was presented in percentages. Chi-square test was used to measure association between sociodemographic characteristics and prevalence of significant bacteriuria, and $p<0.05$ was considered to be statistically significant.

\section{Results:}

A total of 206 pregnant women attending the antenatal clinic of Adeoyo Maternity Hospital, Yemetu, Ibadan, Oyo State, Nigeria, were studied. The age of the participants ranged from 15 to 47 years with a mean age of $28.64 \pm 5.921$ years. Of these 206 women, 18 
had significant bacteriuria, giving the overall prevalence of $8.7 \%, 5(27.8 \%)$ of whom were symptomatic and $13(72.2 \%)$ were asymptomatic (Table 1). Table 2 shows the prevalence of significant bacteriuria with respect to sociodemographic and clinical characteristics of the pregnant women. Chi-square test showed that significant bacteriuria was associated with only pyuria $(p=0.01)$ and past history of UTI $(p=$ $0.004)$, while other factors such as age group, occupation, educational level, parity, gestational age and history of DM were not significantly associated with significant bacteriuria $(p>0.05)$.

From the 18 subjects with significant bacteriuria, 5 bacterial species (all Gram negative and monomicrobial) were isolated, the most prevalent uropathogen was Escherichia coli $50 \%$ (9/18) followed by Klebsiella pneu- moniae $33.3 \%(6 / 18)$, and Pseudomonas aeruginosa $5.6 \%(1 / 18)$, Acinetobacter haemolyticus $5.6 \%(1 / 18)$ and Enterobacter aerogenes $5.6 \%$ (1/18) (Table 3). Antibiotic susceptibility of the bacterial isolates as presented in Table 4 showed that $100 \%, 94.4 \%$, $94.4 \%$, $88.9 \%, 88.2 \%$ and $66.7 \%$ of isolates were sensitive to gentamicin, nitrofurantoin, ceftriaxone, ceftazidime, cefuroxime, and augmentin respectively. Isolates were least sensitive to augmentin, and none of the isolates, including $P$. aeruginosa, were resistant to gentamicin. Escherichia coli, the commonest isolate showed high sensitivity to all tested antibiotics. Conversely, K. pneumoniae showed the highest resistance rate to the antibiotics except gentamicin. Pseudomonas aeruginosa was sensitive to gentamicin and ceftazidime but resistant to nitrofurantoin and augmentin.

Table 1: Frequency of bacteriuria among pregnant women attending the antenatal clinic of Adeoyo Maternity Hospital, Yemetu, Ibadan

\begin{tabular}{ccc}
\hline Bacteriuria/symptomatology & Frequency & Percentage (\%) \\
\hline Significant bacteriuria & 18 & 8.7 \\
Non-significant bacteriuria & 90 & 43.7 \\
Growth of bacterial contaminants & 10 & 4.9 \\
No bacterial growth & 88 & 42.7 \\
Total & $\mathbf{2 0 6}$ & $\mathbf{1 0 0}$ \\
Significant bacteriuria & & 27.8 \\
Symptomatic & 5 & 72.2 \\
Asymptomatic & 13 & $\mathbf{1 0 0}$ \\
Total & $\mathbf{1 8}$ & \\
\hline
\end{tabular}


Table 2: Socio-demographic and clinical characteristics of pregnant women with urinary tract infections attending the antenatal clinic of Adeoyo Maternity Hospital, Yemetu, Ibadan, Nigeria

\begin{tabular}{|c|c|c|c|c|c|}
\hline Characteristics & $\begin{array}{c}\text { No of } \\
\text { patients }(\%)\end{array}$ & $\begin{array}{l}\text { No positive for } \\
\text { bacteria (\%) }\end{array}$ & $\begin{array}{c}\text { Chi square or } \\
\text { Odds Ratio }\end{array}$ & $95 \% \mathrm{CI}$ & $p$ value \\
\hline \multicolumn{6}{|l|}{ Age group (yrs) } \\
\hline $15-20$ & 17 & 1 & 7.26 & - & 0.29 \\
\hline $21-25$ & 54 & 2 & & & \\
\hline $26-30$ & 66 & 5 & & & \\
\hline $31-35$ & 41 & 6 & & & \\
\hline $36-40$ & 21 & 4 & & & \\
\hline $41-45$ & 6 & 0 & & & \\
\hline $46-50$ & 1 & 0 & & & \\
\hline \multicolumn{6}{|l|}{ Educational level } \\
\hline Primary & 25 & 1 & 2.01 & - & 0.57 \\
\hline Secondary & 102 & 8 & & & \\
\hline Tertiary & 76 & 9 & & & \\
\hline No formal education & 3 & 0 & & & \\
\hline \multicolumn{6}{|l|}{ Occupation type } \\
\hline Public & 161 & 13 & 3.81 & - & 0.28 \\
\hline Private & 18 & 1 & & & \\
\hline Self-employed & 20 & 2 & & & \\
\hline Others & 7 & 2 & & & \\
\hline \multicolumn{6}{|l|}{ Parity } \\
\hline 0 & 69 & 6 & 0.65 & - & 0.88 \\
\hline $1-2$ & 88 & 8 & & & \\
\hline $3-4$ & 43 & 3 & & & \\
\hline$>4$ & 6 & 1 & & & \\
\hline \multicolumn{6}{|l|}{ Gestational age } \\
\hline $1^{\text {st }}$ trimester & 25 & 1 & 1.534 & - & 0.46 \\
\hline $2^{\text {nd }}$ trimester & 142 & 12 & & & \\
\hline $3^{\text {rd }}$ trimester & 39 & 5 & & & \\
\hline \multicolumn{6}{|l|}{ Pyuria } \\
\hline Yes & 37 & 18 & 90.09 & $0.38-0.70$ & $0.01 *$ \\
\hline No & 169 & 0 & & & \\
\hline \multicolumn{6}{|l|}{ Past history of UTI } \\
\hline Yes & 84 & 13 & 8.08 & $1.47-12.53$ & $0.004 *$ \\
\hline No & 122 & 5 & & & \\
\hline \multicolumn{6}{|l|}{ History of DM } \\
\hline Yes & 5 & 0 & 0.49 & $1.05-1.15$ & 0.48 \\
\hline No & 201 & 18 & & & \\
\hline
\end{tabular}

Table 3: Frequency distribution of bacteria isolates of significant bacteriuria among pregnant women attending the antenatal clinic of Adeoyo Maternity Hospital, Yemetu, Ibadan, Nigeria

\begin{tabular}{cc}
\hline Bacterial isolate & Frequency (\%) \\
Escherichia coli & $9(50.0)$ \\
Klebsiella pneumoniae & $6(33.0)$ \\
Enterobacter aerogenes & $1(6.0)$ \\
Acinetobacter haemolyticus & $1(6.0)$ \\
Pseudomonas aeruginosa & $1(6.0)$ \\
Total & $\mathbf{1 8 ( 1 0 0 )}$ \\
\hline
\end{tabular}


Table 4: Antibiotic susceptibility of uropathogens of significant bacteriuria in pregnant women attending the antenatal clinic of Adeoyo Maternity Hospital, Yemetu, Ibadan, Nigeria

\begin{tabular}{cccc}
\hline Antibiotics & $\begin{array}{c}\text { No of isolates tested } \\
\text { No of isolate sensitive } \\
(\%)\end{array}$ & $\begin{array}{c}\text { No of isolates resistant } \\
(\%)\end{array}$ \\
\hline Nitrofurantoin (F) & 18 & $17(94.4)$ & $1(5.6)$ \\
Augmentin (AMC) & 18 & $12(66.7)$ & $6(33.3)$ \\
Gentamicin (CN) & 18 & $18(100)$ & 0 \\
Ceftriaxone (CRO) & 18 & $17(94.4)$ & $1(5.6)$ \\
Cefuroxime (CXM) & 18 & $15(88.2)$ & $2(11.8)$ \\
Ceftazidime (CAZ) & 18 & $16(88.9)$ & $2(11.8)$ \\
\hline
\end{tabular}

\section{Discussion:}

Detection of significant bacteriuria in 206 pregnant women (age range 15-47 years) in this study was based on urine culture, which is currently the "gold standard" test for detection of UTI. Although prevalence of significant bacteriuria/UTI and antibiotic susceptibility of bacterial isolates among pregnant women have been reported at different health facilities in Nigeria $(3,6,13-23)$, such data are lacking in our facility, but antibiotic susceptibility of isolates is known to vary according to regional and geographical location and also changes over time, hence the need for this study. The prevalence of $8.7 \%$ for significant bacteriuria in the present study is similar to the rate of $8 \%$ reported by Mandara et al., (13) in Zaria, 8\% by Oyetunji et al, (15) in Sokoto, $9 \%$ by Aminu and Aliyu (23) in Kano, and $9.5 \%$ by Demilie et al., (27) in Bahirdar, Ethiopia, but higher than $1.3 \%$ rate reported by Yakasai et al., (20) in Kano, Nigeria. However, our rate is far lower than $47.5 \%$ reported by Okonko et al., (16) in Ibadan, $54 \%$ by Obiogbolu et al., (18) in Akwa metropolis, and $60 \%$ by Kolawole et al., (6) in Nasarawa, Nigeria. Based on the high prevalence rate in these studies, it was estimated in 2009 that one in two women will have at least one UTI episode in her lifetime while the National Kidney Foundation (NKF) in 2010 (28) estimated one in five women. However, in our study, we estimated this to be one in ten women.

In this study, the frequency of significant bacteriuria among symptomatic pregnant women was $27.8 \%$ compared to $72.2 \%$ among asymptomatic pregnant women. These differ from those reported in studies from Akwa Ibom metropolis in Nigeria ( $0 \%$ vs $54 \%$ ) by Obiogbolu et al., (18), Tanzania (17.9\% vs $13 \%)$ by Masinde et al., (29), Ethiopia (35.3\% vs $22 \%$ ) by Taye et al., (5), and Uganda (53.5\% vs $46.5 \%$ ) by Martin et al., (30). The diffe- rences in these frequencies between study areas might be due to different cultural practices, living standards and category of the study population (31). Our findings indicated that peak prevalence of significant bacteriuria was the second trimester as $66.7 \%$ was reported in the pregnant women during this trimester, which agrees with what has been reported in literature (22). This might be due to the fact that UTI in pregnant women usually begins within week 6 and peaks during week 22-24 of pregnancy due to urethral dilation, increased bladder volume and decreased bladder and urethral tone, which encourage bacterial growth in the urine.

Although bacterial aetiology of UTI can show geographic variations and may vary over time within a population, E. coli $(50 \%)$ was the most commonly isolated urinary pathogen in our study. This is in agreement with reports of other studies by Okonko et al., (16), Taye et al., (5) and Jasmin et al., (32). However, our result is contrary to the findings from some other studies from Nigeria which reported Klebsiella spp., Proteus mirabilis and Staphylococcus aureus to be more prevalent than $E$. coli $(1,20,26)$, although we are careful with the interpretation of our findings because of the small sample size. The second most commonly isolated pathogen in our study was $K$. pneumoniae (33\%), which agrees with the findings of Obiogbolu et al., (18), Onwuezobe et al., (22), and Taye et al., (5). The high frequency of isolation of $K$. pneumoniae implies that this pathogen is gaining prominence as an important aetiologic agent of ASB and UTI in pregnancy over what has been previously reported in many studies $(2,6)$. We noted that there were no Gram-positive bacteria recovered from the urine in significant number among the pregnant women and all significant isolates were monomicrobial, which is similar to the findings of Onwuezobe et al., (22) and Taye et al., (5). The non-contamination of the urine 
observed must have been the result of the urine collection protocol and supervision by nurses and midwives.

Most of the isolated organisms in this study demonstrated a high level of susceptibility to gentamicin $(100 \%)$, nitrofurantoin $(94.4 \%)$, ceftriaxone $(94.4 \%)$ and ceftazidime $(88.9 \%)$, while high level resistance to amoxicillin-clavulanic acid (33.3\%) was observed. The most commonly isolated bacterium, E. coli, was sensitive to gentamicin and nitrofurantoin despite the fact that amoxicillin-clavulanic acid is the most commonly used antibiotic for empirical treatment of UTI in our hospital. Our finding is similar to that of Masinde et al., (29) who reported $94 \%$ of $E$. coli isolates in their study to be sensitive to nitrofurantoin, and to those of Ajayi et al., (19), Akobi et al., (21), and Jasmin et al., (32). Contrary to our study, Assefa et al., (33) reported high sensitivity $(100 \%)$ of their $E$. coli isolates to amoxicillinclavulanic acid in addition to effectiveness of gentamicin and nitrofurantoin. Klebsiella pneumoniae isolates in our study demonstrated highest resistance rates to the tested antibiotics except gentamicin. This may be due to the fact that high proportion of clinical $K$. pneumoniae isolates are now known to carry extended spectrum $\beta$-lactamase (ESBL) and carbapenemase genes, that may contribute to the high resistance rates to the antibiotics tested in this study. This changing pattern in antimicrobial susceptibility with emergence and spread of resistant pathogens has been reported in previous studies $(34,35)$, and this is attributed to inappropriate antimicrobial use as a result of inadequate knowledge about antimicrobial prescriptions and widespread practice of self-medication common in many African settings, among other factors.

\section{Conclusion:}

In view of the high prevalence of asymptomatic significant bacteriuria in pregnancy in this study, routine screening and treatment of symptomatic or asymptomatic pregnant women for this entity should be done in every trimester of the gestational period.

\section{Acknowledgements:}

The authors appreciate the hospital administrators of Adeoyo Maternity Hospital and University College Hospital (UCH), Ibadan, for allowing the use of their facilities for the study. The assistance of laboratory scientists, laboratory technicians, and nurses in the hospital as well as the cooperation of the study participants are gratefully acknowledged.

\section{References:}

1. Omonigho, S. E., Obasi, E. E., and Akukalia, R. N. In vitro Resistance of Urinary Isolates of Escherichia coli and Klebsiella species to Nalidixic Acid. Nig J Microbiol. 2001; 15 (1): 25-29.

2. Ebie, M. Y., Kandakai-Olukemi, Y. T., Ayanbadejo, J., and Tanyigna, K. B. Urinary Tract Infections in a Nigerian Military Hospital. Nig J Microbiol. 2001; 15 (1): 31-37.

3. Dada-Adegbola, H. O., and Muili, K. A. Antibiotic susceptibility pattern of urinary tract pathogens in Ibadan, Nigeria. Afr J Med Sci. 2010; 39: 173179.

4. Yasemi, M., Peyman, H., Asadollahi, K., et al. Frequency of bacteria causing urinary tract infections and their antimicrobial resistance patterns among pediatric patients in Western Iran from 2007-2009. J Biol. Regul Homeostatic Agents. 2014; 28 (3): 443-448.

5. Taye, S., Motuma, G., Zelalem, A. B., and Khan, M. Bacterial profile, antibiotic susceptibility pattern and associated factors among pregnant women with Urinary Tract Infection in Goba and Sinana Woredas, Bale Zone, Southeast Ethiopia. BMC Res Notes. 2018; 11: 799.

6. Kolawole, A. S., Kolawole, O. M., KandakaiOlukemi, Y. T., et al. Prevalence of urinary tract infections (UTI) among patients attending Dalhatu Araf Specialist Hospital, Lafia, Nasarawa State, Nigeria. Int J Med Sci. 2009; 1(5): 163-167.

7. Smaill, F. M., and Vazquez, J. C. Antibiotics for asymptomatic bacteriuria in pregnancy. Cochrane Database Systematic Review. 2015; Issue 8: CD000490.

8. https://www.microbiologybook.org/infectiousdisea se/urinarytractinfections.htm

9. Gunes, G., Gunes, A., Tekiner, S., et al. Bacteriuria and socioeconomic associations among pregnant women in Malatya, Turkey. Publ Hlth. 2005; 19: 1039-1041.

10. Cunningham, F. G., Gant, N. F., and Laveno, K. J. Renal and urinary tract disorders. William Obstetrics. 24th edn, McGraw-Hill Medical Publishing Division, NY. 2014

11. Gilstrap, L. C $3^{\text {rd }}$. and Ramin, S. M. Urinary tract infections during pregnancy. Obstetr Gynecol Clin North Am J. 2001; 28 (3): 581-591.

12. Cunningham, F. G., Gant, N. F., Leveno, K. J., et al. Renal and Urinary Tract Disorders. Williams Obstetr. 21st edn. McGraw-Hill Medical Publishing Division. NY: 2001. 1251-1271.

13. Mandara, M. U., and Shittu, S. O. Asymptomatic Bacteriuria in Antenatal Patients at Ahmadu Bello University Teaching Hospital, Zaria, Nigeria. Trop J Obstetr Gynaecol. 1999; 16 (1): 41-45.

14. Aboderin, A. O., Ako-Nai, A. K., Zailani, S. B., Ajayi, A., and Adedosu, A. N. A study of asymptomatic bacteriuria in pregnancy In Ile-Ife, southwestern Nigeria. Afr J Clin Exper Microbiol. 2004; 5 (3): 252-259.

15. Oyetunji, J. A., Ahmed, Y., Nwobodo, I. E., Airede, L. R., and Ekele, B. A. Asymptomatic bacteriuria in pregnancy in Sokoto, Nigeria. Sahel Med J. 2006; $9(1): 1-6$.

16. Okonko, I. O., Ijandipe, L. A., Ilusanya, O. A., et al. Incidence of urinary tract infection (UTI) among pregnant women in Ibadan, South-Western Nigeria. Afr J Biotechnol. 2009; 8 (23): 66496657.

17. Taiwo, S. S., Adegbite. I. T., and Adefioye, O. A. Asymptomatic bacteriuria in pregnancy in Osogbo with special reference to Staphylococcus saprophyticus. Afr J Infect Dis. 2009; 3(2): 36-43. 
18. Obiogbolu, C. H., Okonko, I. O., Anyamere, C. O., et al. Incidence of Urinary Tract Infections (UTIs) among pregnant women in Akwa metropolis, Southeastern Nigeria. Scientific Research Essay. 2009; 4 (8): 820-824.

19. Ajayi, A. B., Nwabuisi, C., Aboyeji, A. P., Ajayi, N. S., Fowotade, A., and Fakeye, O. O. Asymptomatic Bacteriuria in Antenatal Patients in Ilorin, Nigeria. Oman Med J. 2012; 27 (1): 31-35. doi: $10.5001 /$ omj.2012.06.

20. Yakasai, I. A., Ugwa, E. A., and Garba, D. I. Antimicrobial sensitivity pattern of symptomatic urinary tract infection in pregnancy in Aminu Kano Teaching Hospital. Trop J Obstetr Gynaecol. 2012; 29 (1): 55-59.

21. Akobi, O. A., Inyinbor, H. E, Akobi, E. C., et al. Incidence of Urinary Tract Infection among Pregnant Women Attending Antenatal Clinic at Federal Medical Centre, Bida, Niger-State, North Central Nigeria. Am J Infect Dis Microbiol. 2014; 2 (2): 34-38.

22. Onwuezobe, I., and Orok, F. Associated risk factors of asymptomatic urinary tract infection among pregnant women attending Ante-natal care in a secondary Health care facility in a South-south Nigerian City. Int J Curr Microbiol. Appl Sci. 2015; 8 (8): 223-230.

23. Aminu, K. Y., and Aliyu, U. U. Asymptomatic Bacteriuria in Pregnant Women in the Antenatal Booking Clinic at Aminu Kano Teaching Hospital, Kano, Nigeria. Open J Obstetr Gynecol. 2015; 5: 286-297.

http://dx.doi.org/10.4236/ojog.2015.55042

24. Cheesbrough, M. District laboratory practice in tropical countries part 2. 2nd ed. New York: Cambridge University Press, 2006; 105-114.

25. Bauer, A. W., Kirby, W. M., Sherris, J. C., and Turck, M. Antibiotics susceptibility testing by a standard single disc method. Am J Clin Pathol. 1996; 451: 493-496.

26. Clinical and Laboratory Standards Institute (CLSI). Performance standards for antimicrobial susceptibility testing CLSI supplement M100S. Melvin: M100Ed30E; 30 ${ }^{\text {th }}$ Edition, 2020.
27. Demile, T., Beyene, G., Melaku, S., and Tsegaye, W. Urinary bacterial profile and antibiotic susceptibility pattern among pregnant women in North West Ethiopia. Ethiopia J HIth Sci. 2012; 22: 121-128.

28. National Kidney Foundation (NKF). Urinary Tract Infections. New York, NY 10016. NKF Publication. 2010; 11-10-0205_HBA (www.kidney.org).

29. Masinde, A., Gumodoka, B., Kilonzo, A., and Mshana, S. E. Prevalence of urinary tract infection among pregnant women at Bugando Medical Centre, Mwanza, Tanzania. Tanzania J Hith Res. 2009; 11: 154-159.

30. Martin, O., Adamu, A. A., Julius, T., et al. Prevalence of bacterial urinary tract infections and associated factors among patients attending hospitals in Bushenyi District, Uganda. Int J Microbiol. 2019; Article ID 4246780

31. Shaheen, H. M., Farahat, T. M., and El-Hakeem Hammad, N. A. Prevalence of urinary tract infection among pregnant women and possible risk factors. Menoufia Med J. 2016; 29: 1055-1059.

32. Jasmin, V. J., Arunagirinathan, N., Selvam, R., et al. Urinary Tract Infections during Pregnancy. Int J Innovative Res Sci Engineer Technol. 2019; 8 (7): 2319-8753.

33. Assefa, A., Asrat, D., Woldeamanuel, Y., Hiwot, Y., Afodella, A., and Melesse, T. Bacterial profile and drug susceptibility pattern of urinary tract infection in pregnant women at Tikur Anbessa Specialized Hospital Addis Ababa, Ethiopia. Ethiopia Med J. 2008; 46: 227-235.

34. Olayemi, O., Olayinka, B., and Musa, A. Evaluation of Antibiotic Self-Medication Pattern amongst Undergraduate Students of Ahmadu Bello University (Main Campus), Zaria. Res J Appl Sci Engineer Bact Technol. 2010; 2 (1): 35-38.

35. Ferede, G., Yismaw, G., Wondimeneh, Y., and Sisay, $Z$. The prevalence and antimicrobial susceptibility pattern of bacterial uropathogens isolated from pregnant women. Euro J Exp Biol. 2012; 2 (5): 1497-1502. 